\title{
Masquelet Technique Combined with Tissue Flap Transplantation in The Treatment of Infectious Complex Tissue Defect: A Clinical Analysis
}

\section{Zun REN}

Shanghai Sixth Peoples Hospital

Yubo ZHANG

Shanghai Sixth Peoples Hospital

Jiafei DU

Shanghai Sixth Peoples Hospital

\section{Weijie CAI}

Shanghai Sixth Peoples Hospital

\section{Pengfei CHENG}

Shanghai Sixth Peoples Hospital

Zhengyu XU

Shanghai Sixth Peoples Hospital

Pei HAN ( $\square$ hanpei_cn@163.com )

Shanghai Sixth Peoples Hospital https://orcid.org/0000-0002-6078-3815

\section{Research}

Keywords: Infectious complex tissue defect, Infectious bone defect, Masquelet technique, Flap transplantation

Posted Date: November 10th, 2021

DOI: https://doi.org/10.21203/rs.3.rs-1036124/v1

License: (c) (i) This work is licensed under a Creative Commons Attribution 4.0 International License. Read Full License 


\section{Abstract}

Background: Infectious complex tissue defects have been described as injuries with composite infectious bone defects and extensive soft tissue damage, which are still austere challenges for orthopedists all around the world. The study retrospectively evaluated the Masquelet technique combined with the tissue flap transplantation for the treatment of infectious complex tissue defects and assess key factors of success in this technique.

Methods: From December 2016 to December 2019, 22 patients of infectious complex tissue defects were recruited for the study. All the cases experienced a two-stages treatment. Thorough debridement, stabilization of fracture by external fixation and implantation of a cement spacer mixed with antibiotics in the first stage. Simultaneously, suitable tissue flaps were designed and transplanted for the soft tissue defect. 6-8 weeks later, after the elimination of the infection, the cement spacer was removed carefully from the induced membrane and cancellous bone was grafted into the site of bone defect. The average duration of follow-up was 21 months.

Results: Infection was eliminated after the first stage intervention without recurrence. All the transplanted tissue flaps were survived. Bone union was achieved in all patients in a period of 16-31 weeks following the second stage surgery. According to the Paley fracture healing score, 17 patients showed excellent results and 5 patients displayed good results regarding bone outcomes. When considering functional outcomes, 14 patients exhibited excellent results and 8 patients displayed good results.

Conclusions: This study showed evidences that Masquelet technique combined with tissue flap transplantation was an effective method to repair the infectious complex tissue defects. We also demonstrate that a complete soft-tissue envelope plays an important role in the formation of the induced membrane which promote bone union and in the anti-infection treatment.

\section{Background}

Infectious complex tissue defects have been described as injuries with composite infectious bone defects and extensive soft tissue damage which can lead to increased susceptibility to significant long-term morbidity and disabilities such as amputation [1]. The main causes of the infectious complex defects are open fracture such as Gustilo-Anderson type III trauma and infection after internal or external fixation [2]. According to statistics, the incident of infection for all orthopedic subspecialties ranged from $0.1-30 \%$ and the costs per patient reached up to $\$ 150,000$ [3]. To date, due to the high recurrence rate and high disability rate, the treatment of infectious complex tissue defects is still an austere challenge for orthopedic surgeons.

A wide range of surgical interventions using for treatment of bone defect are reported including free vascularized bone grafting, Papineau bone grafting, llizarov technique, massive allograft transplantation and tissue engineering techniques [4]. The Masquelet technique, also known as induced membrane technique, is one of the treatments that has shown satisfactory outcomes in the management of bone defects [5]. Numerous successful cases have been reported when Masquelet technique was applied in the management of bone defect, nonunion and osteomyelitis [6, 7]. The length of the defect repaired by Masquelet technique can reach $25 \mathrm{~cm}$ [8]. Application of Masquelet technique in the treatment of infectious complex tissue defect has been sparsely reported. In this study, we applied Masquelet technique combined with the tissue flap transplantation to treat infectious complex tissue defects and encouraging outcomes were achieved.

The purpose of this study was to: i) demonstrate our experience with the united use of tissue flap transplantation and Masquelet technique in the management of infectious complex injuries with composite bone and soft tissue defects; ii) assess the clinical effect of this method;

\section{Methods}

This retrospective study was reviewed and approved by the institutional review board, and informed consent was obtained from all patients. 22 patients suffered from infectious complex tissue defect were recruited for the study from December 2016 to December 2019. All patients were managed in the orthopedics department of our hospital. The retrospective study involved 13 males and 9 females with a median age of 47 years (24 - 67 years) at the time of surgery. The sites of bone defects localized on 
tibia (17), radius (1), calcaneus (2), metatarsus (2). 11 cases were caused by the open fracture, 10 infectious defect were caused by infection after internal fixation and 1 case was caused by infection after external fixation.

X-ray plain film and computed tomography (CT) were performed to find out the size of the bone defect. All patients accepted positron emission tomography (PET-CT) examination to identify the scale of the infection. Necrotic tissue and secretions were obtained for bacterial culture and drug sensitivity test to select sensitive antibiotics. All the patients accepted blood routine examination, erythrocyte sedimentation rate (ESR), C-reactive protein (CRP) and procalcitonin (PCT) to detect the condition of the infection.

The whole procedure for the treatment of infectious complex tissue defect is shown in figure1.In the first-stage operation, thorough debridement was performed to remove necrotic and infected tissue until healthy tissue presented. In the cases of infection after internal fixation, the internal fixations were removed. After debridement, external fixators were placed to stabilized the affected bone, the fixation nails should be placed outside the scale of the infection and enough space should be reserved for the tissue flap donor area in this procedure. Deep tissue samples from the debridement were taken for microbiological culture and metagenomic next-generation sequencing (mNGS). A polymethylmethacrylate (PMMA) cement spacer mixed with antibiotics was implanted in the site of the bone defect. We designed tissue flaps to cover the wound according to the location and size of the soft tissue defect. 15 local perforator tissue flaps, 3 free flaps and 1 groin flap, were used in this study. In addition, 3 muscle flaps were combined with the skin graft. The temperature and color of the flaps were monitored in order to judge perfusion and venous conditions. Antispasmodic and anticoagulant medications were administered intravenously for five days post-operatively.

6 to 8 weeks later, PET-CT and blood exams were reexamined. When the white blood cell count, ESR, CRP and PCT was within the normal range, result of PET-CT showed no infection signs and clinical signs of infection were precluded, the second stage operation was performed. The healed wound was carefully incised, and a well-formed induced membrane was split longitudinally to remove the cement spacer. Samples of tissues were taken for intraoperative frozen section diagnosis. If the intraoperative frozen section reported less than 5 neutrophils per high power field, the bone graft could be performed. The anterior superior iliac spine was resected and cut into autologous granular cancellous bone. These cancellous pieces mixed with allogeneic granular cancellous bone were inserted into the site of the bone defect and the induced membrane was preserved and sutured. Internal fixations were applied for the fracture stabilization. External fixation maintained if the bone defect was large.

Post-operatively, we permitted patients to ambulate with protected weight bearing and encourage them to perform joint range of motion exercise. Clinical and radiological follow-up were performed every 4-6 weeks before bone union. Bone growth results, functional results and relative complications were checked every 3 months for the following period. At the final follow-up, the fracture healing index was assessed using the Paley fracture healing score.

\section{Results}

22 patients were followed up for an average of 21.3 (12 to 36) months. All patients were diagnosed as infectious complex tissue defects according to the clinical and imaging examinations. The demographic and clinical characteristics are shown in Table 1.

3 cases repeated the first stage operation when the PET-CT results showed sign of infection before the second stage operation. Infection was eliminated without recurrence in all patients. Microbiological cultures from tissue samples tested positive in 13 cases and the results of mNGS showed positive in 19 cases. The bacteria found in the site of infection including Staphylococcus aureus, Enterobacter cloacae, Enterococcus faecalis, Enterococcus faecium, Pseudomonas aeruginosa, Streptococcus viridans, Clostridium perfringens, Actinomyces radingae and Anaerococcus hydrogenalis.

The tissue flap size ranged from $6 * 3 \mathrm{~cm}^{2}$ to $21 * 10 \mathrm{~cm}^{2}$. All the transplanted tissue flaps were survived. Necrosis was occurred on the edge in 3 flaps, but the complete coverage of wound was not affected. All soft tissue defects were successfully repaired after the first stage intervention. 
Bone union was achieved in all patients at a mean of 22.2 weeks (12 to 31 weeks). The mean interval between the two stages was 7.7 weeks (range 6 to 11 weeks). The median length of the bone defect was $5.4 \mathrm{~cm}$ (range 3.0 to $13.6 \mathrm{~cm}$ ). Redness and swelling appeared around the external nail in 4 patients. These symptoms vanished after the external fixations were removed. At the final follow-up, all patients displayed full weight-bearing capacity with no assistive device. According to the Paley fracture healing score (Table2) [9], 17 patients showed excellent results and 5 patients displayed good results in bone outcomes. When considering functional outcomes, 14 patients exhibited excellent results and 8 patients displayed good results. 
Table 1

Demographic and clinical characteristics of the patients.

\begin{tabular}{|c|c|c|c|c|c|c|c|c|c|}
\hline ID & $\begin{array}{l}\text { Gender/Age } \\
\text { (years) }\end{array}$ & Etiology & $\begin{array}{l}\text { Site of } \\
\text { defect }\end{array}$ & $\begin{array}{l}\text { Bone } \\
\text { defect } \\
\text { (cm) }\end{array}$ & $\begin{array}{l}\text { Size } \\
\text { of } \\
\text { flaps } \\
\left(\mathrm{cm}^{2}\right)\end{array}$ & $\begin{array}{l}\text { Type } \\
\text { of } \\
\text { flaps }\end{array}$ & $\begin{array}{l}\text { Microbiological } \\
\text { culture }\end{array}$ & mNGS & $\begin{array}{l}\text { Bone } \\
\text { union } \\
\text { time } \\
\text { (weeks) }\end{array}$ \\
\hline 1 & $\mathrm{M} / 37$ & $\begin{array}{l}\text { Infection } \\
\text { after } \\
\text { external } \\
\text { fixation }\end{array}$ & Tibia & 6.6 & $7 * 4$ & $\begin{array}{l}\text { muscle } \\
\text { flap }\end{array}$ & $\begin{array}{l}\text { Enterobacter } \\
\text { cloacae }\end{array}$ & Mixed infection & 20 \\
\hline 2 & $\mathrm{M} / 67$ & $\begin{array}{l}\text { Infection } \\
\text { after } \\
\text { internal } \\
\text { fixation }\end{array}$ & Tibia & 3.3 & $12 * 6$ & $\begin{array}{l}\text { local } \\
\text { flap }\end{array}$ & / & $\begin{array}{l}\text { Clostridium } \\
\text { perfringens }\end{array}$ & 27 \\
\hline 3 & $\mathrm{~F} / 50$ & $\begin{array}{l}\text { Open } \\
\text { fracture }\end{array}$ & Tibia & 2.2 & $15 * 9$ & $\begin{array}{l}\text { free } \\
\text { flap }\end{array}$ & $\begin{array}{l}\text { Staphylococcus } \\
\text { aureus }\end{array}$ & $\begin{array}{l}\text { Staphylococcus } \\
\text { aureus }\end{array}$ & 30 \\
\hline 4 & $\mathrm{M} / 24$ & $\begin{array}{l}\text { Open } \\
\text { fracture }\end{array}$ & Radius & 10.3 & $20 * 6$ & $\begin{array}{l}\text { groin } \\
\text { flap }\end{array}$ & $\begin{array}{l}\text { Pseudomonas } \\
\text { aeruginosa }\end{array}$ & $\begin{array}{l}\text { Pseudomonas } \\
\text { aeruginosa }\end{array}$ & 31 \\
\hline 5 & $M / 34$ & $\begin{array}{l}\text { Infection } \\
\text { after } \\
\text { internal } \\
\text { fixation }\end{array}$ & Calcaneus & 5.2 & $10 * 3$ & $\begin{array}{l}\text { local } \\
\text { flap }\end{array}$ & $\begin{array}{l}\text { Staphylococcus } \\
\text { aureus }\end{array}$ & $\begin{array}{l}\text { Staphylococcus } \\
\text { aureus }\end{array}$ & 28 \\
\hline 6 & $F / 61$ & $\begin{array}{l}\text { Infection } \\
\text { after } \\
\text { internal } \\
\text { fixation }\end{array}$ & Tibia & 4.9 & $7 \star 3$ & $\begin{array}{l}\text { local } \\
\text { flap }\end{array}$ & / & $\begin{array}{l}\text { Streptococcus } \\
\text { viridans }\end{array}$ & 26 \\
\hline 7 & $\mathrm{M} / 33$ & $\begin{array}{l}\text { Open } \\
\text { fracture }\end{array}$ & Tibia & 4.2 & $9 * 4$ & $\begin{array}{l}\text { muscle } \\
\text { flap }\end{array}$ & Escherichia coli & Escherichia coli & 24 \\
\hline 8 & $F / 58$ & $\begin{array}{l}\text { Open } \\
\text { fracture }\end{array}$ & Tibia & 6.5 & $8 * 4$ & $\begin{array}{l}\text { local } \\
\text { flap }\end{array}$ & I & Mixed infection & 27 \\
\hline 9 & $F / 42$ & $\begin{array}{l}\text { Infection } \\
\text { after } \\
\text { internal } \\
\text { fixation }\end{array}$ & Tibia & 5.3 & $23 * 7$ & $\begin{array}{l}\text { free } \\
\text { flap }\end{array}$ & $\begin{array}{l}\text { Enterococcus } \\
\text { faecalis }\end{array}$ & Mixed infection & 24 \\
\hline 10 & $F / 63$ & $\begin{array}{l}\text { Open } \\
\text { fracture }\end{array}$ & Tibia & 7.7 & $8 * 5$ & $\begin{array}{l}\text { local } \\
\text { flap }\end{array}$ & $\begin{array}{l}\text { Pseudomonas } \\
\text { aeruginosa }\end{array}$ & $\begin{array}{l}\text { Pseudomonas } \\
\text { aeruginosa }\end{array}$ & 22 \\
\hline 11 & $\mathrm{M} / 46$ & $\begin{array}{l}\text { Infection } \\
\text { after } \\
\text { internal } \\
\text { fixation }\end{array}$ & Tibia & 6.2 & $7 * 4$ & $\begin{array}{l}\text { muscle } \\
\text { flap }\end{array}$ & $\begin{array}{l}\text { Enterobacter } \\
\text { cloacae }\end{array}$ & Mixed infection & 19 \\
\hline 12 & $M / 64$ & $\begin{array}{l}\text { Open } \\
\text { fracture }\end{array}$ & Tibia & 8.7 & $11 * 5$ & $\begin{array}{l}\text { local } \\
\text { flap }\end{array}$ & / & / & 23 \\
\hline 13 & $\mathrm{M} / 53$ & $\begin{array}{l}\text { Infection } \\
\text { after } \\
\text { internal } \\
\text { fixation }\end{array}$ & Tibia & 7.2 & $6 * 3$ & $\begin{array}{l}\text { local } \\
\text { flap }\end{array}$ & / & / & 16 \\
\hline 14 & $\mathrm{M} / 57$ & $\begin{array}{l}\text { Infection } \\
\text { after } \\
\text { internal } \\
\text { fixation }\end{array}$ & Tibia & 3.5 & $7 * 4$ & $\begin{array}{l}\text { local } \\
\text { flap }\end{array}$ & $\begin{array}{l}\text { Staphylococcus } \\
\text { aureus }\end{array}$ & $\begin{array}{l}\text { Staphylococcus } \\
\text { aureus }\end{array}$ & 20 \\
\hline 15 & $F / 35$ & $\begin{array}{l}\text { Open } \\
\text { fracture }\end{array}$ & Tibia & 7.8 & $12 \star 4$ & $\begin{array}{l}\text { local } \\
\text { flap }\end{array}$ & $\begin{array}{l}\text { Enterobacter } \\
\text { cloacae }\end{array}$ & $\begin{array}{l}\text { Enterobacter } \\
\text { cloacae }\end{array}$ & 25 \\
\hline
\end{tabular}




\begin{tabular}{|c|c|c|c|c|c|c|c|c|c|}
\hline ID & $\begin{array}{l}\text { Gender/Age } \\
\text { (years) }\end{array}$ & Etiology & $\begin{array}{l}\text { Site of } \\
\text { defect }\end{array}$ & $\begin{array}{l}\text { Bone } \\
\text { defect } \\
\text { (cm) }\end{array}$ & $\begin{array}{l}\text { Size } \\
\text { of } \\
\text { flaps } \\
\left(\mathrm{cm}^{2}\right)\end{array}$ & $\begin{array}{l}\text { Type } \\
\text { of } \\
\text { flaps }\end{array}$ & $\begin{array}{l}\text { Microbiological } \\
\text { culture }\end{array}$ & mNGS & $\begin{array}{l}\text { Bone } \\
\text { union } \\
\text { time } \\
\text { (weeks) }\end{array}$ \\
\hline 16 & $F / 38$ & $\begin{array}{l}\text { Open } \\
\text { fracture }\end{array}$ & Tibia & 6.7 & $12 * 8$ & $\begin{array}{l}\text { local } \\
\text { flap }\end{array}$ & $\begin{array}{l}\text { Staphylococcus } \\
\text { aureus }\end{array}$ & Mixed infection & 22 \\
\hline 17 & $\mathrm{M} / 41$ & $\begin{array}{l}\text { Infection } \\
\text { after } \\
\text { internal } \\
\text { fixation }\end{array}$ & Calcaneus & 6.3 & $12 * 4$ & $\begin{array}{l}\text { local } \\
\text { flap }\end{array}$ & / & $\begin{array}{l}\text { Clostridium } \\
\text { perfringens }\end{array}$ & 31 \\
\hline 18 & $F / 35$ & $\begin{array}{l}\text { Open } \\
\text { fracture }\end{array}$ & Metatarsus & 2.1 & $21 * 10$ & $\begin{array}{l}\text { free } \\
\text { flap }\end{array}$ & $\begin{array}{l}\text { Enterococcus } \\
\text { faecium }\end{array}$ & Mixed infection & 17 \\
\hline 19 & $\mathrm{M} / 47$ & $\begin{array}{l}\text { Open } \\
\text { fracture }\end{array}$ & Metatarsus & 1.7 & $12 * 4$ & $\begin{array}{l}\text { local } \\
\text { flap }\end{array}$ & $\begin{array}{l}\text { Staphylococcus } \\
\text { aureus }\end{array}$ & $\begin{array}{l}\text { Staphylococcus } \\
\text { aureus }\end{array}$ & 12 \\
\hline 20 & $M / 58$ & $\begin{array}{l}\text { Infection } \\
\text { after } \\
\text { internal } \\
\text { fixation }\end{array}$ & Tibia & 3.2 & $16 * 6$ & $\begin{array}{l}\text { local } \\
\text { flap }\end{array}$ & $\begin{array}{l}\text { Pseudomonas } \\
\text { aeruginosa }\end{array}$ & $\begin{array}{l}\text { Pseudomonas } \\
\text { aeruginosa }\end{array}$ & 16 \\
\hline 21 & $\mathrm{M} / 61$ & $\begin{array}{l}\text { Open } \\
\text { fracture }\end{array}$ & Tibia & 4.2 & $8 * 4$ & $\begin{array}{l}\text { local } \\
\text { flap }\end{array}$ & / & / & 18 \\
\hline 22 & $F / 49$ & $\begin{array}{l}\text { Open } \\
\text { fracture }\end{array}$ & Tibia & 5.3 & $17 * 6$ & $\begin{array}{l}\text { local } \\
\text { flap }\end{array}$ & $\begin{array}{l}\text { Staphylococcus } \\
\text { aureus }\end{array}$ & Mixed infection & 12 \\
\hline
\end{tabular}

* F: female; M: male; mNGS: microbiological metagenomic next-generation sequencing;

Table 2 Evaluation Criteria of Bone and Functional Results

\begin{tabular}{|c|c|c|c|}
\hline $\begin{array}{l}\text { Bone } \\
\text { results }\end{array}$ & Criteria & $\begin{array}{l}\text { Functional } \\
\text { results }\end{array}$ & Criteria \\
\hline Excellent & $\begin{array}{l}\text { Union, no infection, deformity }<7^{\circ}, \\
\text { limb length discrepancy (LLD) }<2.5 \mathrm{~cm}\end{array}$ & Excellent & $\begin{array}{l}\text { Active, no limp, minimum stiffness (loss of } \\
<15^{\circ} \text { knee extension } /<15^{\circ} \text { ankle dorsiflexion), } \\
\text { no reflex sympathetic dystrophy (RSD), } \\
\text { insignificant pain. }\end{array}$ \\
\hline Good & $\begin{array}{l}\text { Union plus any two of the following: } \\
\text { absence of infection, deformity }<7^{\circ} \text {, } \\
\text { LLD }<2.5 \mathrm{~cm} \text {. }\end{array}$ & Good & $\begin{array}{l}\text { Active, with one or two of the following: limb, } \\
\text { stiffness, RSD, significant pain }\end{array}$ \\
\hline Fair & $\begin{array}{l}\text { Union plus any one of the following: } \\
\text { absence of infection, deformity }<7^{\circ} \text {, } \\
\text { LLD }<2.5 \mathrm{~cm}\end{array}$ & Fair & $\begin{array}{l}\text { Active, with three or all of the following: limb, } \\
\text { stiffness, RSD, significant pain }\end{array}$ \\
\hline Poor & $\begin{array}{l}\text { Nonunion/refracture/union plus } \\
\text { infection plus deformity }>7^{\circ} \text { plus } \\
\text { LLD }>2.5 \mathrm{~cm}\end{array}$ & Poor & $\begin{array}{l}\text { Inactive (unemployment or inability to return to } \\
\text { daily activities because of injury) }\end{array}$ \\
\hline
\end{tabular}

\section{Discussion}

Because of the the high recurrence rate and high disability rate, the infectious complex tissue defect is still a conundrum for orthopedic surgeons. It also brings heavy burden to the patients. Effective treatments for the disease are rarely reported. In this 
study, we applied Masquelet technique combined with tissue flaps transplantation to address the issue and achieved promising results.

For the management of infection, we took a very prudential strategy. The treatment of infection just like a war against bacteria. We need to know where and who are the enemies. PET-CT examination before the first debridement could offer an explicit range of the infection, which was an important reference for the thorough and accurate debridement. Thorough debridement of infectious bone and soft tissue is the most crucial factor to prevention of infection recurrence $[9,10]$. Deep tissue from the debridement was taken for both microbiological culture and mNGS to identify the pathogen. These results were going to guide the application of antibiotics. The mNGS had a higher positive rate in the study and identified more mixed infection. mNGS can get the results in 24-36 hours while microbiological culture takes a few days. Although the microbiological culture is still the gold standard of pathogen diagnosis, in our procedure, we combined microbiological culture and mNGS that can improve the speed and accuracy of the diagnosis. During the first stage operation, the antibiotic-impregnated cements were inserted in the site of the bone defect. Local antibiotics usage is characterized by high local concentration and low systemic toxicity which has strong capacity to eradicate infection in the bone defect site. Patients underwent the second PET-CT before the second stage operation. If the reports showed no infection signs, then the second stage operation could be proceeded, else the first stage operation will be repeated. During the second stage operation, intraoperative frozen sections were taken to assure the security of the bone defect reconstruction. The prudential strategy is the key factor for the success of the treatment of infectious complex tissue defect.

The optimal timing for antibiotic-impregnated cements removal was described as 6-8 weeks, according to Masquelet [11]. At this time, the induced membrane is rich in vascularization and high concentration of growth factors, conducive to osteogenesis [12]. Theoretically, the effectiveness of the Masquelet technique depends on the quality of the vascularized membrane. In our study, the interval ranged from 6 to 11 weeks, mainly to eradicate maximum infection. The average time to bone union was 22.2 weeks, which was consistent with the previous studies $[9,13]$.

According to the basic surgical principles for the management of Gustilo III open fractures, early soft tissue coverage has been proven crucial and effective during the treatment $[14,15]$. Tissue flaps transplantation can offer soft tissue coverage for the wound, increase blood supply, defend against infection, and improve bone healing [16]. For Masquelet technique, the complete soft tissue envelope of the site of the bone defect assists the formation of a complete and well vascularized induced membrane which is crucial for the reconstruction of the bone defect $[17,18]$. What's more, the closure of the wound in the first stage operation can provide great confidence to the patients. An optimistic attitude is also important for the healing.

The united of llizarov technique and tissue transfer has also been reported as an effective method for limb salvage in composite injuries. However, the drawbacks of this technique including long treatment time, joint stiffness, and high technical requirement should not be ignored [19]. Compared the Masquelet technique combined with tissue flap transplantation and other treatments of infectious complex tissue defects such as llizarov technique and free vascularized bone grafting. The former had the advantages of simple surgical operation, reliable treatment effect and relatively short treatment cycle.

Although this study demonstrated the reliable results of the Masquelet technique combined with tissue flap transplantation in the treatment of infectious complex tissue defects, there are some limitations. For the long segmental bone defects in the lower extremities, we don't recommend this technique because of the difficulty of fracture stability and the grafted bone resorption. The limitations of our study are the small number of cases, the lack of a direct comparison with a control group. A prospective study with more cases should be performed to get more convincible conclusions.

\section{Conclusion}

The Masquelet technique combined with the tissue flap transplantation provides an effective and reliable protocol for the treatment of infectious complex tissue defects, which simplifies surgical procedures and improves the success rate of limb salvage. Moreover, firm fixation is crucial to this technique. While considering the small number of individual cases in this study, a multicenter controlled comparative trial may be necessary to determine the real potential of this technique in the treatment of such complex tissue defects.

Page $7 / 10$ 


\section{Declarations}

The study was approved by the Independent Ethics Committee of Shanghai Jiao Tong University Affiliated Sixth People's Hospital. Informed consents were obtained from all participants. The datasets used and/or analyzed during the current study are available from the corresponding author on reasonable request. The authors declare that they have no competing interests. This work was sponsored by the National Natural Science Foundation of China (No.81974325, No. 81702183) and the Science and Technology Commission of Shanghai Municipality (No.18ZR1428700).

RZ and ZYB analyzed and interpreted the patient data regarding the infectious complex tissue defect and edit the manuscript. CWJ, DJF and CPF collected the follow-up data of the patients. HP and XZY provided technical suggestions and reviewed the manuscript. All authors read and approved the final manuscript.

\section{References}

1. Hu R, Ren YJ, Yan L, Yi XC, Ding F, Han Q, Cheng WJ, et al. Analysis of Staged Treatment for Gustilo Anderson IIIB/C Open Tibial Fractures. Indian J Orthop. 2018; 52: 411-417.

2. Schmitt SK. Osteomyelitis. Infect Dis Clin North Am. 2017 Jun;31(2):325-338.

3. Schwarz EM, Parvizi J, Gehrke T, et al. 2018 International consensus meeting on musculoskeletal infection: research priorities from the general assembly questions[J]. J Orthop Res. 2019; 37(5):997-1006.

4. Wang J, Yin Q, Gu S, Wu Y, Rui Y. Induced membrane technique in the treatment of infectious bone defect: A clinical analysis. Orthop Traumatol Surg Res. 2019 May;105(3):535-539.

5. Wang P, Wu Y, Rui Y, Wang J, Liu J, Ma Y. Masquelet technique for reconstructing bone defects in open lower limb fracture: Analysis of the relationship between bone defect and bone graft. Injury. 2021 Apr;52(4):988-995.

6. Masquelet AC, Kishi T, Benko PE. Very long-term results of post-traumatic bone defect reconstruction by the induced membrane technique. Orthop Traumatol Surg Res. 2019 Feb;105(1):159-166.

7. Careri S, Vitiello R, Oliva MS, Ziranu A, Maccauro G, Perisano C. Masquelet technique and osteomyelitis: innovations and literature review. Eur Rev Med Pharmacol Sci. 2019 Apr;23(2 Suppl):210-216.

8. Masquelet AC, Begue T. The concept of induced membrane for reconstruction of long bone defects. Orthop Clin North Am. 2010 Jan;41(1):27-37;

9. Deng L, Yu A, Qi B, Lei J, De Souza C, Zhu S, Yu L. The Masquelet technique combined with the muscle flap for use in emergency management of acute Gustilo type III trauma of the lower limb with segmental bone loss:Case series. Int J Surg. 2020 Sep;81:85-93.

10. Abdou SA, Stranix JT, Daar DA, Mehta DD, McLaurin T, Tejwani N, Saadeh PB, Levine JP, Leucht P, Thanik VD. Free Tissue Transfer with Distraction Osteogenesis and Masquelet Technique Is Effective for Limb Salvage in Patients with Gustilo Type IIIB Open Fractures. Plast Reconstr Surg. 2020 Apr;145(4):1071-1076.

11. Masquelet A, Kanakaris NK, Obert L, Stafford P, Giannoudis PV. Bone Repair Using the Masquelet Technique. J Bone Joint Surg Am. 2019 Jun 5;101(11):1024-1036.

12. Gindraux F, Loisel F, Bourgeois M, Oudina K, Melin M, de Billy B, Sergent P, et al. Induced membrane maintains its osteogenic properties even when the second stage of Masquelet's technique is performed later. Eur J Trauma Emerg Surg. 2020 Apr;46(2):301-312.

13. Taylor BC, Hancock J, Zitzke R, Castaneda J. Treatment of Bone Loss With the Induced Membrane Technique: Techniques and Outcomes. J Orthop Trauma. 2015 Dec;29(12):554-7.

14. Cherubino M, Corno M, Ronga M, Riva G, di Summa PG, Sallam D, Tamborini F, Maggiulli F, Surace M, Valdatta L. The AdipoFascial ALT Flap in Lower Extremities Reconstruction Gustillo IIIC-B Fractures. An Osteogenic Inducer? J Invest Surg. 2021 Jun;34(6):638-642.

15. Wang CY, Chai YM, Wen G, Han P. One-stage reconstruction of composite extremity defects with a sural neurocutaneous flap and a vascularized fibular graft: a novel chimeric flap based on the peroneal artery. Plast Reconstr Surg. 2013 
Sep;132(3):428e-437e.

16. Cherubino M, Stocco C, Ronga M, Tamborini F, Maggiulli F, Di Giovanna D, Campisi C, Di Summa P, Valdatta L. Comparisons of fascio-cutaneous anterolateral thigh and sandwich fascial ALT free flap in the distal extremity reconstruction.

Microsurgery. 2020 May;40(4):452-459.

17. Tarchala M, Harvey EJ, Barralet J. Biomaterial-Stabilized Soft Tissue Healing for Healing of Critical-Sized Bone Defects: the Masquelet Technique. Adv Healthc Mater. 2016 Mar;5(6):630-40.

18. Lou TF, Wen G, Wang CY, Chai YM, Han P, Yin XF. L-shaped corticotomy with bone flap sliding in the management of chronic tibial osteomyelitis: surgical technique and clinical results. J Orthop Surg Res. 2019 Feb 12;14(1):47.

19. Liu Y, Yushan M, Liu Z, Liu J, Ma C, Yusufu A. Complications of bone transport technique using the llizarov method in the lower extremity: a retrospective analysis of 282 consecutive cases over 10 years. BMC Musculoskelet Disord. 2020 Jun $6 ; 21(1): 354$.

\section{Figures}

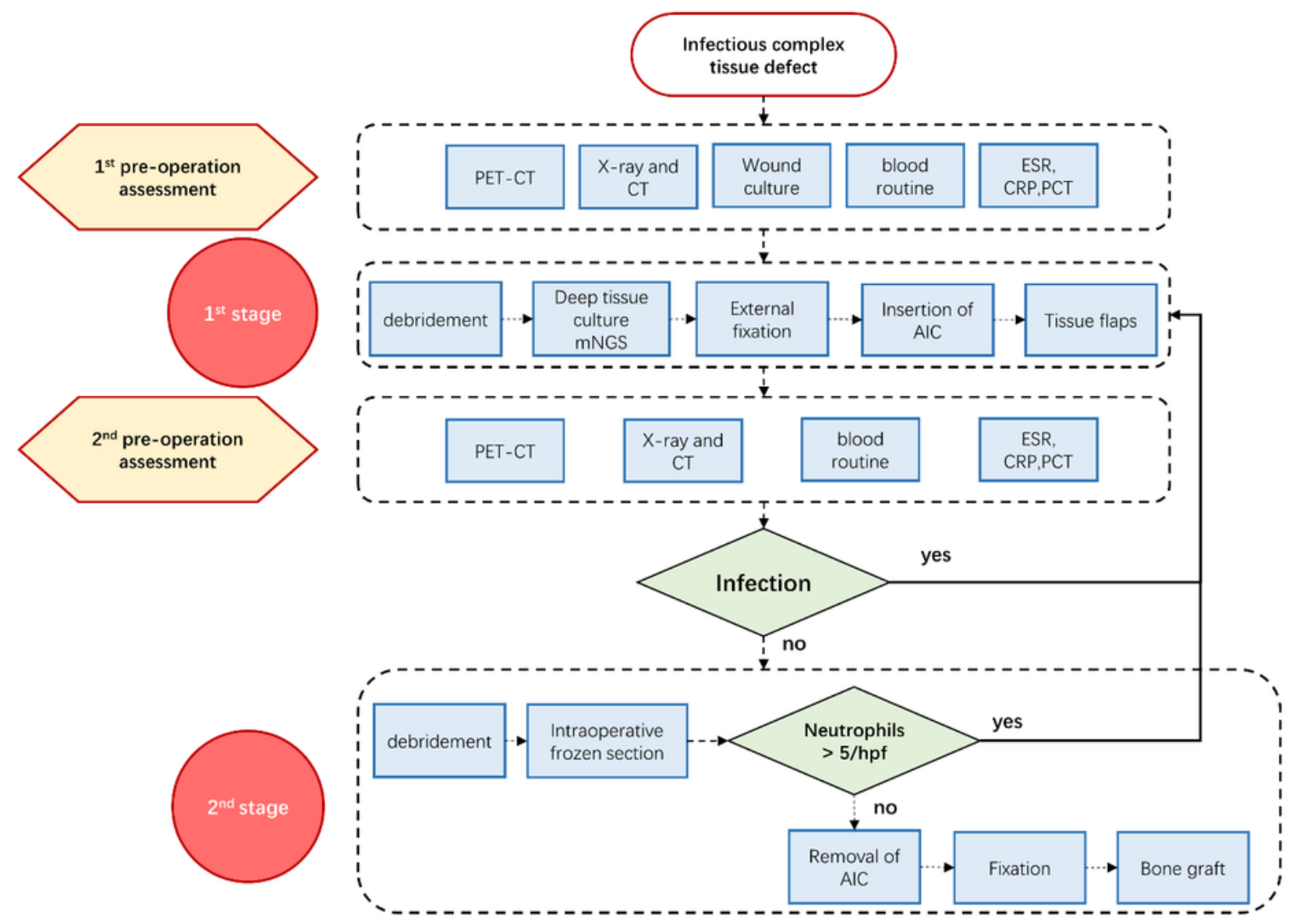

Figure 1

Procedure for the treatment of infectious complex tissue defect.

Figure 2

Case 1 A 37-year-old male was admitted to our hospital due to the infection of new bone after distraction osteogenesis of left tibia, which combined with soft-tissue defect. a) PET-CT showed infection of new bone after after distraction osteogenesis. b), c) and d) defects of bone and soft-tissue after debridement, bone defect was implanted with antibiotic cement and soft tissue defect was repaired with gastrocnemius flap and skin graft. e) and f) autologous bone graft was performed 8 weeks after the 
first-stage operation. The grafted bone was fixed by screws and the external fixation was remained. g) and h) wound healing and bone union were achieved.
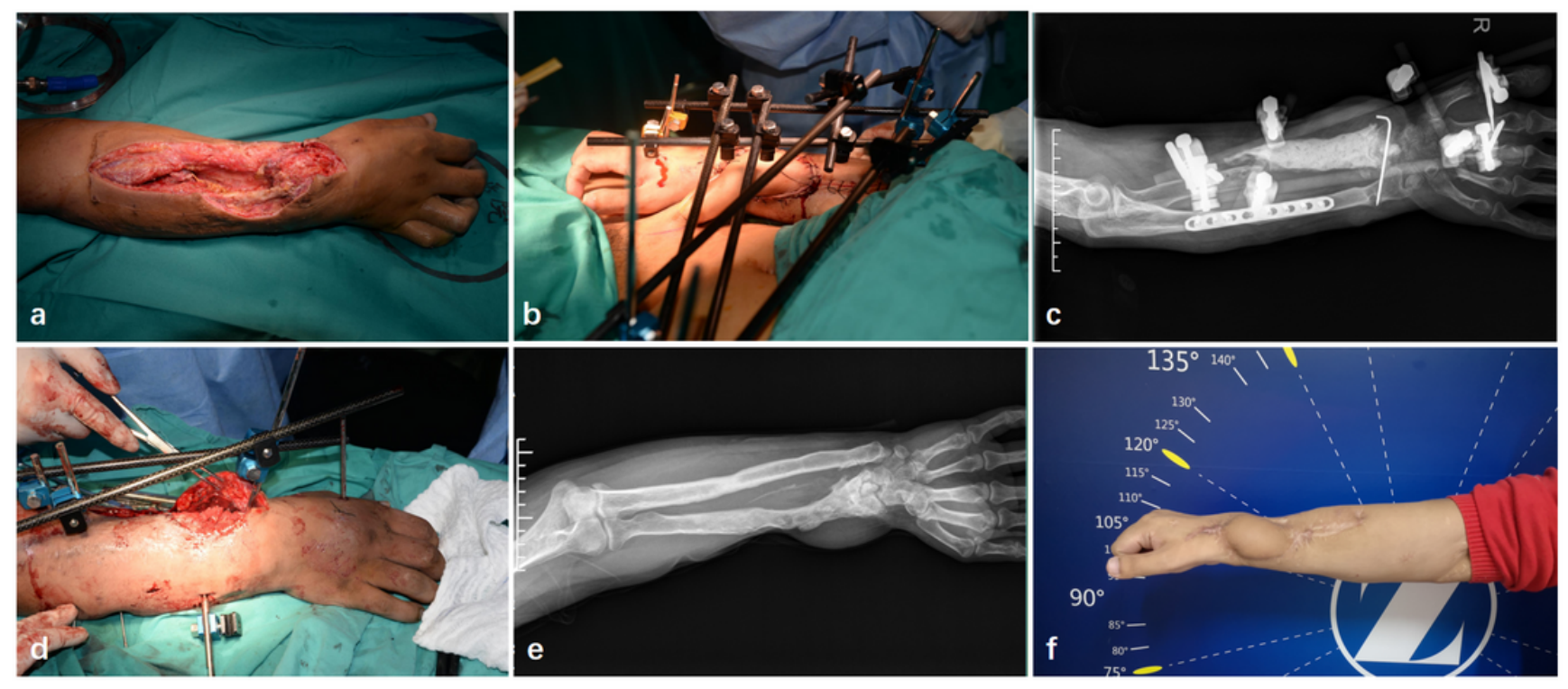

\section{Figure 3}

Case 2 A 24-year-old male suffered from infection by Pseudomonas aeruginosa after open fracture in right radius. a) large segmental bone defect $(10.3 \mathrm{~cm})$ and extensive soft tissue damage were presented after the aggressive debridement. b) and c) antibiotic cement was implanted in the site of bone defect and a groin flap was performed to cover the soft tissue defect. d) autologous bone graft was performed 7 weeks after the first-stage operation. The external fixation was remained. e) and f) wound healing and bone union were achieved. 